\title{
Seminal Plasma Proteome: Promising Biomarkers for Bull Fertility
}

\author{
Pradeep Kumar • D. Kumar • Inderjeet Singh • \\ P. S. Yadav
}

Received: 21 October 2011 / Accepted: 3 December 2011/Published online: 19 January 2012

(C) NAAS (National Academy of Agricultural Sciences) 2012

\begin{abstract}
The seminal plasma is a mixture of secretions from the testis, epididymis and male accessory sex glands. A number of seminal plasma proteins are associated with male fertility but most of these have not been studied in detail till now. Recently, proteomics has been used to show the differences in proteins profile in seminal plasma from high and low fertility bulls. For example, osteopontin, phospholipase A2, P25b, acidic seminal fluid proteins, $\alpha$-L-fucosidase and cathepsin D are positively correlated with fertility of bulls and may act as useful fertility marker (s), while lipocalin-type prostaglandin D synthase, spermadhesin Z13, clusterin and ubiquitin are negatively correlated with fertility in bulls. Bovine seminal plasma proteins in seminal plasma act like a double-edged sword and showed a quadratic association with bull fertility. The physiological roles of the metalloproteinase-2 (TIMP-2), ecto-ADP-ribosyltransferase 5, nuclobindin, Niemann-Pick C2 and epididymal sperm-binding protein 1 and their relationship to bull fertility need further studies. This review summarizes the physiological functions of proteins of seminal plasma and their relation to bull fertility.
\end{abstract}

Keywords Bull $\cdot$ Proteomics $\cdot$ Fertility $\cdot$ Seminal plasma proteins

\section{Introduction}

For successful artificial insemination (AI) in cattle and buffalo, bull fertility is essential to assure optimal reproductive efficiency. Routinely used traditional semen quality tests provide limited information about the potential fertility of bulls. Computer assisted semen analyser (CASA) commonly used these days to evaluate semen quality, does not provide high correlation or even consistent results with bull fertility index. Several studies have been conducted in the past decades in the search of exact and potential fertility markers in bulls. Mammalian seminal plasma is a complex mixture of secretions originated from testis, epididymis and male accessory sex glands (seminal vesicles, ampulla, prostate and bulbourethral glands) which contains a variety of proteins that modulate the fertilizing ability of sperm [46]. A number of

P. Kumar $(\bowtie) \cdot$ D. Kumar · I. Singh · P. S. Yadav Buffalo Physiology and Reproduction Division, Central Institute for Research on Buffaloes, Sirsa Road, Hisar 125001, India e-mail: drpradeepkrvet@gmail.com seminal plasma proteins have been investigated which act as molecular markers of fertility in different species. Based on the literature available on the characterization of these proteins, most of the studies had been conducted in the order: bull $>>$ boar $>>$ stallion $>$ buck $>$ ram $>$ poultry [37].

After spermatogenesis and spermiation, spermatozoa are not capable to fertilize an oocyte. The fertilizing ability is acquired during the transit of the spermatozoa through the male and female reproductive tract. During transportation, spermatozoa acquire and interact with variety of proteins from epididymal fluid and accessory gland fluids which play very significant role to achieve motility, oocyte binding as well as penetrating capacity and fertilizing ability $[1,86]$. Beside these, seminal plasma proteins are also potentially involved in sperm membrane protection, prevention of oxidative stress, anti-microbial activity, capacitation, acrosome reaction and early embryonic development [48-50,59 ]. Despite the great importance of these proteins, only few have been studied in detail $[8,10$, 20, 46-50] and in most cases our understanding of their precise role and relationships with male fertility is obscure. 
In the pre-proteomics era, two dimensional (2D) gel electrophoresis coupled with immunostaining was the method of choice to visualize the whole proteome. Unfortunately, in this method all spots on gels cannot be identified due to the large number of proteins in the seminal plasma. In recent years, the development of mass spectrometric (MS) technique is used to identify large number of proteins spots resolved on the 2D gel electrophoresis from very complex mixture of proteins. Interestingly, proteomics has identified large number of proteins that are differentially expressed in sperm membrane, seminal plasma, accessory sex gland fluid and epididymal fluid of fertile and sub fertile bulls [10, 48-50]. Moura et al. [49, 50] reported a comprehensive protein profile of cauda epididymal fluid and accessory gland fluid of bulls and detected an average of 108 and 52 spots respectively on 2D gels. In this review, we will discuss our current understanding of the physiological functions of proteins of seminal plasma and their relation to bull fertility.

\section{Seminal Plasma Proteins}

The understanding of physiological functions of seminal plasma proteins will give idea how to reduce infertility and improve fertility in breeding bulls. Research conducted on bovine seminal plasma indicates that some specific proteins in semen are related to fertility but still function and relationships with fertility indexes are incomplete for many seminal proteins. The specific seminal plasma proteins related to fertility of bull are discussed below.

\section{Bovine Seminal Plasma Proteins}

Bovine seminal plasma proteins (BSPs) secreted by the seminal vesicles belong to family of heparin-binding proteins and represent approximately $70 \%$ of the total protein content of bovine seminal plasma [51]. The most common proteins of bovine seminal plasma are represented by three acidic proteins, designated as BSP-A1/-A2, BSP-A3 and BSP-30 (collectively called BSPs). The BSP-A1/-A2 and BSP-A3 have molecular weight of $15-16 \mathrm{kDa}$, whereas BSP-30 has 28-30 kDa [41]. The BSP-A1/-A2 also known as PDC-109 (Protein with N-terminus aspartic acid D and carboxy terminus Cystine, having 109 amino acids) is a mixture of BSP-A1 and BSP-A2, which differ only in glycosylation [42]. Recently, many similar seminal proteins have been discovered in other mammalian species which are causing inconsistency in the nomenclature and are creating confusion. Therefore, Manjunath et al. [45] proposed a new nomenclature in collaboration with the HUGO Gene Nomenclature Committee and BSP-A1/A2, BSP-A3 and BSP-30 are now called BSP1, BSP3 and
BSP5, respectively and BSPs are collectively called as binder of sperm.

At ejaculation, sperms are mixed with seminal plasma for a short period and during this short period of exposure; BSPs remove some (5-8\%) cholesterol (1st cholesterol efflux) from the sperm membrane [78]. On the other hand, BSPs also bind to choline phospholipids of sperm plasma membrane [11, 44]. This activity prevents the free movement of phospholipids and stabilizes the sperm membrane. As the sperm reach the oviduct, sperm-bounded BSPs interact with the capacitation factors (such as high-density lipoprotein (HDL) and heparin) and potentiate sperm capacitation induced by HDL and heparin by stimulating cholesterol and phospholipid efflux from the sperm membrane [78]. BSPs are also involved in forming an oviductal sperm reservoir by enabling sperm to bind with oviductal epithelium [29]. This binding maintains the sperm motility until the oocyte reaches the site of fertilization. Normally, the BSPs do not stimulate lipid efflux during capacitation unless certain capacitating agents are present, such as heparin or HDL $[78,80]$. In this way, oviductal epithelium via the BSPs, stabilize the sperm until capacitating agents enter the storage area to initiate capacitation. During capacitation, BSPs are lost from the sperm and the sperm lose binding affinity for the oviductal epithelium. Thus, the loss of BSPs during capacitation plays a major role in release of sperms from the reservoir [28, 29]. Thus, BSPs play a crucial role in fertilization by maintaining sperm motility during storage [29]. In contrast to the beneficial role of BSPs in fertility, they may also have deleterious effects during the sperm storage. It has been shown that the cholesterol efflux induced by BSP proteins is dependent on exposure time and concentration. It could be deleterious to the sperm membrane if get more exposure and concentration [78, 79]. Furthermore, [42] observed that the BSP proteins bind to the low-density fraction (LDF) of a lipoprotein component of the egg yolk (EY) extender and that binding is rapid, specific, saturable and stable even after freeze-thawing of semen. The binding of BSPs to LDF may prevent their detrimental effect on sperm membrane, and this may be crucial for sperm storage [42]. Thus, they proposed that the sequestration of BSPs by LDF may represent the major mechanism of sperm protection by EY. Therefore, BSPs in seminal plasma may be beneficial or detrimental to sperm depending on the concentration and exposure time. Moura et al. [49] suggested that this protective action is probably not sufficient in the case of bulls with high concentrations of BSPs in the accessory sex gland fluid/seminal plasma. Roncoletta et al. [60] found the higher concentrations of BSP-A3 in the membrane of the low fertile bull. Therefore, BSP proteins in seminal plasma act like a double-edged sword, being both beneficial and detrimental to sperm. 
Lipocalin-Type Prostaglandin D Synthase

Gerena et al. [20] identified the fertility-associated $26 \mathrm{kDa}$ seminal plasma protein as lipocalin- type prostaglandin D synthase (L-PGDS) through the use of N-terminal sequencing, immunoblotting and enzymatic assays. Basically, L-PGDS is a member of the family of transport proteins and has various physiological roles including sleep induction, regulation of body temperature and smooth muscle contraction and relaxation [83], but exact role of L-PGDS in male reproduction is unknown. However, L-PGDS have been identified on elongating spermatids, Sertoli cells, rete testis, efferent duct epithelial cells along with epididymal epithelial cells and the apical ridge of the acrosome on ejaculated bovine sperm. It may play an important role in both development and maturation of sperm [20, 21]. Its relationship to overall male fertility may be the result of its ability to function as a transmembrane lipophilic carrier protein to maintain the blood-testis and blood-epididymal barriers [21]. Higher expression of L-PGDS in seminal plasma is associated with high fertility in bulls [20,38] where as Moura et al. [48] observed higher expression of L-PGDS in epididymal fluid of bulls of low fertility. Jobim et al. [36] also found that L-PGDS is associated with seminal plasma samples from bulls of low freezability than from bulls with high semen freezability. More work is required to explore the role of L- PGDS in bull fertility.

\section{Phospholipase A2}

Phospholipase A2 (PLA2) are ubiquitous enzymes, present in most cells and tissues, and act on membrane phospholipids releasing fatty acid from the second carbon group of glycerol backbone with concomitant formation of lysophospholipid. The newly released free fatty acid affects the cellular function and the concomitantly generated lysophospholipid may act on cellular membrane. PLA2 has also been found on the plasma membrane as well as in the acrosome and post-acrosomal substance of ejaculated bull sperm [84]. It has a molecular weight of $60 \mathrm{kDa}$ and $\mathrm{pI} 5.6$ [69] while an isoform $16 \mathrm{kDa}$ PLA2 [62] has also been detected. It has been shown that PLA-2 is attached on the surface of ejaculated bull sperm but not on the epididymal sperm [61]. It plays important roles in the late maturational events of spermatozoa, the acrosomal reaction and spermegg fusion [67, 87]. The PLA2 attached to sperm membranes, synthesizes arachidonic acid, which is converted to prostaglandin E2, leading to events related to acrosome reaction [4]. The membrane-bound PLA2 may be stimulated or inhibited depending on the local concentration of BSPs [44]. BSPs may sequester choline phospholipids on the sperm surface and thereby block PLA2 from acting on these phospholipids and prevent sperm from undergoing a premature acrosome reaction [44]. There is also evidence that PLA2 stimulates immune cells [27] and has antimicrobial activity in the seminal plasma [3, 85]. The expressions of PLA2 are more in the accessory sex gland fluid of high fertility bulls than in low fertility bulls [49].

\section{Osteopontin}

Killian et al. [38] found four fertility-associated proteins in the bull seminal plasma, one of them later identified as osteopontin (OPN). OPN is a highly acidic glycoprotein that was initially isolated from the mineralized matrix of bovine diaphysial bone [18]. Later on it was detected in several tissues and fluids, including non-osteogenic cells. In general, OPN is associated with cell adhesion, tissue remodelling, immune cell stimulation, chemotaxis, and cell survival, inhibition of calcium oxalate crystallization, intracellular signalling, cytoskeleton dynamics and tumour metastasis. It is very interesting that this multifunctional protein is also found in the male reproductive tract and associated with fertility. This protein is expressed in the ampullae, seminal vesicles and epididymis of different species. It is likely that the different isoforms of OPN detected in different portion of bull reproductive tract with different functions [16]. In the seminiferous tubules, where it is synthesized by Sertoli and germ cells, OPN is potentially involved in binding these germ cells to the basement membrane of the seminiferous tubule and to adjacent Sertoli cells [40]. In bull, OPN expressed only in the seminiferous tubules containing elongated spermatids suggesting a stage-related expression pattern [58]. OPN promotes capacitation of sperm through unknown way and increase sperm viability possibly by blocking apoptotic pathways [16]. OPN interacts with the membrane of ejaculated bull sperm and also affects sperm-oocyte binding and early embryonic development [50, 70]. Souza et al. [70] proposed mechanisms by which OPN bind to sperm at ejaculation, possibly through integrin and/or CD44 receptors. According to this mechanism, OPN remain bound to sperm until it reaches the site of fertilization. Link of sperm-bound OPN with integrin and/or CD44 receptors on oocyte membrane would inevitably trigger intracellular signalling, affecting post-fertilization events [70]. Thus, this mechanism explains why exogenous OPN has positive effects on early embryo development in vitro. Addition of antibodies against OPN to the IVF medium causes significant reductions in the percentage of fertilization of oocytes [24]. OPN is associated with an increased capacity of sperm to penetrate the oocyte [50] and prevention of polyspermy in porcine [30] and bovine [16]. The functional role of OPN on male fertility may be indirect. Brown et al. [5] assumed that luminal OPN binds to integrin receptors 
located on the epithelial surface and protect these epithelial cells from bacterial infections and influence host defences in inflammatory conditions. In this way, OPN also involve in male fertility indirectly by protecting epithelial surfaces of the accessory sex glands from bacterial infections. OPN was found in more amounts in the accessory sex gland fluid of high fertile bulls than in low fertile bulls [48].

\section{Acidic Seminal Fluid Protein}

An acidic seminal fluid protein (aSFP), molecular weight $13 \mathrm{kDa}$, was first purified from bovine semen showed growth factor-like activity [13]. Later on, the aSFP was detected in secretions of ampulla and seminal vesicles, but not in testis, epididymis or blood of bulls [14]. Bovine aSFP belongs to the spermadhesin protein family [6]. In the pig, spermadhesins are a group of $12-14 \mathrm{kDa}$ spermassociated lectins which appear to mediate sperm binding to extracellular coat of the oocyte zona pellucida [81]. However, unlike the porcine spermadhesins, aSFP binds only loosely to the sperm surface at ejaculation but lost after capacitation [12]. Dostilovi et al. [12] suggested that the bull spermatozoa surface may be completely depleted of spermadhesin aSFP before spermatozoa reach the surroundings of the investing egg. Therefore, aSFP may act as a decapacitation factor on bull spermatozoa rather than as a zona pellucida binding molecule. In vitro, the motility of ejaculated bovine spermatozoa was significantly decreased at highest aSFP levels but was restored after dilution, indicating that the reversible inhibition of spermatozoal motility may be caused by a specific interaction between aSFP and spermatozoa but aSFP did not affect the viability of spermatozoa [68]. In the bull, spermatozoa are temporarily stored in the ampulla prior to ejaculation, where high aSFP levels restrict motility as an energy-preserving mechanism [68] but in the female reproductive tract loosely attached aSFP is diluted out, allowing for rapid restoration of sperm motility [12]. In this way, it is assumed that high amounts of aSFP in ampulla prevent spermatozoa from wasting energy on ejaculation, but it could stimulate their activity after dilution in the female genital tract [68]. The aSFP also protect spermatozoa from oxidative damage by diminishing lipid peroxidation at its physiological concentration [15]. Higher concentration of aSFP was found in semen from high freezability bull as compared to semen from low freezability bull [36].

\section{P25b}

$\mathrm{P} 25 \mathrm{~b}$, member of a family of xylulose reductases, secreted by the epididymal epithelium and attached to the testicular sperm surface during the epididymal transit [55], is associated with the plasma membrane that covers the acrosomal cap of spermatozoa [55]. Epididymosomes are released in cauda epididymal fluid through apocrine secretion by the epithelial cells bordering the epididymal lumen. The epididymosomes transfer this protein from the epididymal lumen to sperm surface which is $\mathrm{pH}$, temperature, and zinc dependant [19]. It may be involved in the binding the spermatozoa to the surface of the egg and acquisition of sperm fertilizing ability [64, 73]. Thus, spermatozoa acquire this property during epididymal transit and this protein is considered as a marker of epididymal maturation of male gametes. The amount of P25b associated with spermatozoa shows individual variation, and low levels of $\mathrm{P} 25 \mathrm{~b}$ are found in spermatozoa from bulls of lower fertility [55]. During the cryopreservation, this surface protein, $\mathrm{P} 25 \mathrm{~b}$, is exposed to cryoinjuries and also assumed that partly cryoeluted from the surface of frozen-thawed sperm [39]. The loss of P25b occurring during cryopreservation decrease frozen-thawed semen fertilizing ability [39]. Duration of storage in liquid nitrogen and the extender used to cryopreserve bull spermatozoa both affect the level of P25b present on sperm surface [39]. Lessard et al. [39] found that a milk-based extender is more efficient than egg yolk in protecting sperm against the protein cryoelution that occurs during cryopreservation. Thus, P25b is a potential marker of sperm maturation and fertility loss associated with freezing-thawing procedures.

\section{Spermadhesin Z13}

Killian et al. [38] found that the spermadhesin was abundant in seminal plasma of bulls of low fertility and named it anti-fertility factor. Subsequently, it was identified as the spermadhesin Z13. The spermadhesin Z13 appears as two $13 \mathrm{kDa}$ monomers in 2D SDS PAGE of bovine seminal plasma, which are assumed to originate from a $26 \mathrm{kDa}$ dimer [77]. Similarly, Moura et al. [49] identified a spermadhesin Z13 spot in the accessory sex gland fluid gels at $29 \mathrm{kDa}$. Spermadhesin Z13 shows 50 and $43 \%$ homology with the aSFP and seminal plasma motility inhibitor, respectively [77]. The spermadhesin Z13 binds to the surface of sperm [82]. Moura et al. [48] suggested lower fertility of bulls with high levels of spermadhesin Z13 due to adverse effect of this protein on sperm motility. Thus, this protein has an inverse relationship with bull fertility.

\section{Clusterin}

Clusterin was first identified in ram rete testis fluid where it showed signs of clustering with rat Sertoli cells and erythrocytes [2], hence its name. Clusterin, 75-80 kDa disulfide-linked heterodimeric protein, is also known as sulfated glycoprotein-2, testosterone-repressed prostate message-2, apolipoprotein $\mathrm{J}$ and complement lysis 
inhibitor. It is expressed in most mammalian tissues and associated with the clearance of cellular debris and apoptosis. The protein has been implicated in many diverse physiological processes such as programmed cell death, regulation of complement mediated cell lysis, membrane recycling, cell-cell adhesion, lipid transportation, sperm maturation, tissue remodelling, stabilization of stressed proteins in a folding-competent state and src induced transformation. In the male reproductive tracts, it is produced by Sertoli cells and principal epididymal epithelial cells [76] and is translocated to abnormal germ cells and spermatozoa [34]. However, Ibrahim et al. [32] found as 70 and $40 \mathrm{kDa}$ isoforms of clusterin in the accessory gland fluid are similar to those reported in the cauda epididymis fluid of bulls. Ibrahim et al. [32] also found that several isoforms of clusterin occur in the bull reproductive tract and the variation in carbohydrate content among these isoforms may affect the biological or functional activity of the protein. Clusterin in male reproductive tracts is involved in various physiological processes such as it binds and agglutinates abnormal spermatozoa in bulls, prevent oxidative damage to the sperm, inhibit complementinduced sperm lysis $[32,52,57]$. Sephadex filtration is a semen evaluation assay that was introduced by Graham et al. [26]. Filtration of bull semen through these columns removed immotile, dead and abnormal spermatozoa, and improved non-return rates of low fertility bulls from 61 to $67 \%$ [25]. It was suggested that changes in the sperm surface structure rather than motility determines whether or not sperm will pass through the filters [9]. Subsequently, the trapping of abnormal spermatozoa in the filters was hypothesized to depend on the exposure of a clusterin-like molecule on the spermatozoa [66]. In human and bull semen, antibodies raised against the dimeric form of clusterin bind only to abnormal sperm cells [53]. Ibrahim et al. [34] suggested that the percentage of clusterin positive sperm cells in semen could be a useful marker in poorquality ejaculates. The presence of clusterin on ejaculated sperm may indicate improper spermatogenesis or irregular epididymal maturation [33]. Thus, clusterin is a protein that shows an inverse relationship with fertility.

\section{Ubiquitin}

Ubiquitin was first isolated from bovine thymus in 1975 as $8.5 \mathrm{kDa}$ protein but later detected in all eukaryotic cells [23]. In general, ubiquitin binds to proteins and directs to the proteasome, which is a large protein complex in the cell that degrades and recycles unneeded proteins. The Nobel Prize in Chemistry for 2004 was awarded jointly to Aaron Ciechanover, Avram Hershko and Irwin Rose for the discovery of ubiquitin-mediated protein degradation. In the male reproductive tract, ubiquitin is secreted by epididymis
[74]. In the bull epididymal fluid, prostasome-like secretory particles, epididymosomes transfer epididymis-secreted proteins to the bull sperm plasma membrane [19]. Such ubiquitin-containing epididymosomes arise from the release of the apical blebs from the epididymal epithelial lining [31, 74]. Sutovsky et al. [74] discovered that arylsulfatase $\mathrm{A}$ is one of the sperm surface proteins ubiquitinated in the defective spermatozoa. Increased ubiquitin levels in bull sperm are indication of both poor semen quality and fertility in bulls. The ubiquitin is a suitable marker of sperm abnormalities because it covalently links to the surface of defective mammalian spermatozoa [74]. It can be detected by ubiquitin-based sperm quality assays which are relatively easy and not costly to perform [75].

\section{Some Others Seminal Plasma Proteins}

$\alpha$-L-fucosidase is detected in seminal plasma, epididymal fluid and on spermatozoa of bull $[35,72]$. The cauda epididymidis is the main source of $\alpha$-L-fucosidase in the bull [72]. Moura et al. [48] also detected $\alpha$-L-fucosidase in the cauda epididymal fluid of bulls having molecular weight $54.4 \mathrm{kd}$ and $\mathrm{pI} 6.6$ and was asscociated with high-fertility bulls. $\alpha$-L-fucosidase is possibly involved in the modification of carbohydrate moieties of sperm membrane proteins during epididymal transit and was found in lower amounts in the seminal plasma of bulls with more percentage of abnormal sperm [35]. The pure enzyme promoted the acrosome reaction of guinea pig spermatozoa in vitro [72].

In the male reproductive tract, cathepsin $\mathrm{D}$, found in cauda epididymal fluid [48], may participate in the proteolytic remodeling of membrane components of sperm during epididymal transit. The intensity of cathepsin $\mathrm{D}$ in 2D maps of the cauda epididymal fluid was 2.4 fold greater in high-fertility bulls than in low-fertility bulls [48]. Apolipoprotein A-I is a component of HDL [71], and is suggested to be involved in sperm cholesterol efflux and capacitation $[43,79]$. The metalloproteinase-2 (TIMP-2) is found as $24 \mathrm{kDa}$ heparin binding protein in bovine seminal plasma [7, 50]. It is suggested that TIMP-2 influences fertility of bulls, either through inhibition of metalloprotease activity in semen or via undefined activities independent of matrix metalloproteinase (MMP) inhibition [47]. However, precise role and mechanism of action of TIMP-2 in relation to bull fertility are currently under investigation.

The ecto-ADP-ribosyltransferase 5 (ART 5, $43 \mathrm{kDa}, \mathrm{pI}$ 6.3) has been identified in the accessory sex gland fluid [50]. However, its physiological role in male reproduction and relation to fertility is not known. Nucleobindin (58 $\mathrm{kDa}, \mathrm{pI} 5)$ a protein with $\mathrm{Ca}^{2+}$ and DNA-binding motifs was first time identified in accessory sex gland fluid 
by Moura et al. [50]. Interestingly, like OPN, nucleobindin has also been associated with bone cells and odontoblasts [56]. Thus another bone protein was identified in the bull seminal plasma and accessory sex gland fluid but its role in fertility is obscure.

Niemann-Pick C2 (NPC2), high-affinity cholesterolbinding protein, is secreted by epididymis of various species $[17,22,54]$. This protein is thought to be involved in cholesterol transport during sperm maturation [22]. NPC2 in the bovine seminal plasma acts as a membrane reorganization factor in a capacitation- independent process [22]. The epididymal sperm-binding protein 1 (ELSPBP1) is having highly regionalised expression in the epididymis [63]. Their distinct spatial expression patterns along the epididymal duct suggest that ELSPBP1 may have a role in sperm maturation [65].

\section{Concluding Remarks}

The physiological functions and their relation to bull fertility of a number of seminal plasma proteins have been studied in details. BSPs are involved in stabilisation of sperm membrane, formation of sperm reservoir in the oviduct, maintaining sperm viability in sperm reservoir, inhibition of PLA2 activity and capacitation. However, BSPs in seminal plasma act like a double-edged sword, being both beneficial and detrimental to sperm. L-PGDS is associated with development and maturation of sperm. The trans membrane lipophilic carrier proteins maintains the blood-testis and blood-epididymal barrier. The role of L-PGDS on bull fertility is contradictory. PLA2 plays important roles in acrosomal reaction and sperm-egg fusion and is associated with semen of high fertility bulls. OPN is involved in protecting epithelial surfaces of the accessory sex glands from bacterial infections, binding germ cells to the basement membrane of the seminiferous tubule and to adjacent Sertoli cells, sperm-oocyte binding, fertilization process, blocking to polyspermy and early embryonic development. OPN is a significant marker of bull fertility and abundant in the seminal plasma of bulls with high fertility. aSFP protects spermatozoa from oxidative damage, influence sperm motility and more amount of aSFP is found in the bull semen with high freezability. P25b, a marker of epididymal maturation of sperm, is involved in binding of spermatozoa to the ovum and low levels of P25b are found in spermatozoa from bulls of lower fertility. Spermadhesin Z13, an anti-fertility factor, adversely effects sperm motility. Clusterin binds and agglutinate abnormal spermatozoa, prevent oxidative damage to the sperm, inhibit complement-induced sperm lysis and act as a useful marker of poor-quality ejaculates. Ubiquitin is a suitable marker of sperm abnormalities because it covalently links to the surface of defective mammalian spermatozoa. Beside these, other proteins like $\alpha$-L-fucosidase, cathepsin D, ART5, TIPM-2 and NPC2 are also found in seminal plasma with different functions but their relation to bull fertility need to be further investigated. Due to advancement of techniques and technologies in this area the future research will probably be directed towards detailed proteomic studies of low/abundant protein (s) components in fertile and subfertile bulls which will help in better understanding of exact function of seminal plasma proteins and their relationship to fertility.

Conflict of interest Authors declare no conflict of interest.

\section{References}

1. Amann RP, Griel LC Jr (1974) Fertility of bovine spermatozoa from rete testis, cauda epididymis and ejaculated sperm. J Dairy Sci 57:212-219

2. Blaschuk O, Burdzy K, Fritz IB (1983) Purification and characterization of a cell-aggregating factor (clusterin), the major glycoprotein in ram rete testis fluid. J Biol Chem 25:7714-7720

3. Bourgeon F, Evrard B, Brillard-Bourdet M, Colleu D, Jegou B, Pineau C (2004) Involvement of semenogelin derived peptides in the antibacterial activity of human seminal plasma. Biol Reprod 70:768-774

4. Breitbart H, Spungin B (1997) The biochemistry of the acrosome reaction. Mol Hum Reprod 3:195-202

5. Brown LF, Berse B, Van de Water L, Papadopoulos-Sergiou A, Perruzzi CA, Manseau EJ, Dvorak HF, Senger DR (1992) Expression and distribution of osteopontin in human tissues: widespread association with luminal epithelial surfaces. Mol Biol Cell 3:1169-1180

6. Calvete JJ, Sanz L, Dostalovi Z, Topfer-Petersen E (1995) Spermadhesins: sperm-coating proteins involved in capacitation and zona pellucida binding. Fertilirat 2:35-40

7. Calvete J, Varela P, Sanz L, Romero A, Mann K, Topfer-Petersen E (1996) Procedure for large-scale isolation of major bovine seminal plasma proteins. Protein Expr Purif 8:48-56

8. Cancel AM, Chapman DA, Killian GJ (1997) Osteopontin is the 55-kilodalton fertility-associated protein in Holstein bull seminal plasma. Biol Reprod 57:1293-1301

9. Crabo BG, Loseth KJ, Weidel L (1992) Trapping of morphological types of bull spermatozoa by Sephadex/glass wool filters. In: Proceedings of the 12 th international congress on animal reproduction. The Hague, The Netherlands, pp 423-425

10. D'Amours O, Frenette G, Fortier M, Leclerc P, Sullivan R (2010) Proteomic comparison of detergent-extracted sperm proteins from bulls with different fertility indexes. Reproduction 139:545-556

11. Desnoyers L, Manjunath P (1992) Major proteins of bovine seminal plasma exhibit novel interactions with phospholipid. J Biol Chem 267:10149-10155

12. Dostilovi Z, Calvete JJ, Sanz L, Hettel C, Riedel D, Schoneck C, Einspanier R, Topfer-Petersen E (1994) Immunolocalization and quantitation of acidic seminal fluid protein (aSFP) in ejaculated, swim-up, and capacitated bull spermatozoa. Biol Chem Hoppe Seyler 375:457-461

13. Einspanier R, Einspanier A, Wempe F, Scheit KH (1991) Characterization of a new bioactive protein from bovine seminal fluid. Biochem Biophys Res Commun 179:1006-1010 
14. Einspanier R, Amselgruber W, Sinowatz F, Henle Th, Ropke R, Schams D (1993) Localization and concentration of a new bioactive acetic seminal fluid protein (aSFP) in bulls (Bos taurus). J Reprod Fertil 98:241-244

15. Einspanier R, Krause I, Calvete JJ, Topfer-Petersen E, Klostermeyer H, Karg H (1994) Bovine seminal plasma aSFP: Localization of disulphide bridges and detection of three different isoelectric forms. FEBS Lett 344:61-64

16. Erikson DW, Way AL, Chapman DA, Killian GJ (2007) Detection of osteopontin on Holstein bull spermatozoa, in cauda epididymal fluid and testis homogenates, and its potential role in bovine fertilization. Reproduction 133:909-917

17. Fouchecourt S, Metayer S, Locatelli A, Dacheux F, Dacheux JL (2000) Stallion epididymal fluid proteome: qualitative and quantitative characterization; secretion and dynamic changes of major proteins. Biol Reprod 62:1790-1803

18. Franzen A, Heinegard D (1985) Isolation and characterization of two sialoproteins present only in bovine calcified matrix. Biochem J 232:715-724

19. Frenette G, Lessard C, Sullivan R (2002) Selected proteins of "prostasome-like particles" from epididymal cauda fluid are transferred to epididymal caput spermatozoa in bull. Biol Reprod 67:308-323

20. Gerena RL, Irikura D, Urade Y, Eguchi N, Chapman DA, Killian GJ (1998) Identification of a fertility associated protein in bull seminal plasma as lipocalin-type prostaglandin D synthase. Biol Reprod 58:826-833

21. Gerena RL, Irikura D, Eguchi N, Urade Y, Killian GJ (2000) Immunocytochemical localization of lipocalin-type prostaglandin D synthase in the bull testis and epididymis and on ejaculated sperm. Biol Reprod 62:547-556

22. Girouard J, Frenette G, Sullivan R (2008) Seminal plasma proteins regulate the association of lipids and proteins within detergent-resistant membrane domains of bovine spermatozoa. Biol Reprod 78:921-931

23. Goldstein G, Scheid MS, Hammerling V, Boyse EA, Schlesinger DH, Niall HD (1975) Isolation of a polypeptide that has lymphocyte-differentiating properties and is probably represented universally in living cells. Proc Natl Acad Sci USA 72:11-15

24. Goncalves RF, Wolinetz CD, Killian GJ (2007) Influence of arginine-glycine-aspartic acid (RGD), integrins (alphaV and alpha5) and osteopontin on bovine sperm-egg binding, and fertilization in vitro. Theriogenology 67:468-474

25. Graham EF, Graham JK (1990) The effect of whole ejaculate filtration on the morphology and fertility of bovine semen. J Dairy Sci 73:91

26. Graham EF, Vazquez IA, Schmehl MKL, Evensen BK (1976) An assay of semen quality by use of sephadex filtration. In: 7th international congress on animal reproduction and artificial insemination, vol IV. Cracow, pp 896-899

27. Granata F, Petraroli A, Boilard E, Bezzine S, Bollinger J, DelVecchio L, Gelb MH, Lambeau G, Marone G, Triggiani M (2005) Activation of cytokine production by secreted phospholipase A2 in human lung macrophages expressing the M-type receptor. J Immunol 174:464-474

28. Gwathmey TM, Ignotz GG, Suarez SS (2003) PDC-109 (BSPA1/A2) promotes bull sperm binding to oviductal epithelium in vitro and may be involved in forming the oviductal sperm reservoir. Biol Reprod 69:809-815

29. Gwathmey TM, Ignotz GG, Mueller JL, Manjunath P, Suarez SS (2006) Bovine seminal plasma proteins PDC-109, BSP-A3, and BSP-30- $\mathrm{kDa}$ share functional roles in storing sperm in the oviduct. Biol Reprod 75:501-507

30. Hao Y, Mathialagan N, Walters E, Mao J, Lai L, Becker D, Li W, Critser J, Prather RS (2006) Osteopontin reduces polyspermy during in vitro fertilization of porcine oocytes. Biol Reprod 75:726-733

31. Hermo L, Jacks D (2002) Nature's ingenuity: Bypassing the classical secretory route via apocrine secretion. Mol Reprod Dev 63:394-410

32. Ibrahim NM, Troedsson MHT, Foster DN, Loseth KJ, Farris JA, Blaschuk O, Crabo BG (1999) Reproductive tract secretions and bull spermatozoa contain different clusterin isoforms that cluster cells and inhibit complement- induced cytolysis. J Androl 20:230-240

33. Ibrahim NM, Gilbert GR, Loseth KJ, Crabo BG (2000) Correlation between clusterin-positive spermatozoa determined by flow cytometry in bull semen and fertility. J Androl 21:887-893

34. Ibrahim NM, Romano JE, Troedsson MHT, Crab BGO (2001) Effect of scrotal insulation on clusterin-positive cells in ram semen and their relationship to semen quality. J Androl 22:863-877

35. Jauhiainen A, Vanha-Perttula T (1986) $\alpha$-L-Fucosidase in the reproductive organs and seminal plasma of the bull. Biochim Biophys Acta 880:91-95

36. Jobim MIM, Oberst ER, Salbego CG, Souza DO, Wald VB, Tramontina F, Mattos RC (2004) Two-dimensional polyacrylamide gel electrophoresis of bovine seminal plasma proteins and their relation with semen freezability. Theriogenology 61:255-266

37. Jonakova V, Jonak J, Ticha M (2010) Proteomics of male seminal plasma. In: Zhihua J, Troy LO (eds) Reproductive genomics in domestic animals. Wiley-Blackwell, Iowa, pp 339-366

38. Killian GJ, Chapman DA, Rogowski LA (1993) Fertilityassociated proteins in bull seminal plasma. Biol Reprod 49: 1202-1207

39. Lessard C, Parent S, Leclerc P, Bailey JL, Sullivan R (2000) Cryopreservation alters the level of a potential bull fertility marker. J Androl 21:700-707

40. Luedtke CC, McKee MD, Cyr DG, Gregory M, Kaartinen MT, Mui J, Hermo L (2002) Osteopontin expression and regulation in the testis, efferent ducts, and epididymis of rats during postnatal development through to adulthood. Biol Reprod 66:1437-1448

41. Manjunath P (1984) Gonadotropin release and stimulatory and inhibitory proteins in bull seminal plasma. In: Sairam MR, Atkinson LE (eds) Gonadal proteins and peptides and their biological significance. World Scientific Publishing Company, Singapore, pp 49-61

42. Manjunath P, Therien I (2002) Role of seminal plasma phospholipid-binding proteins in sperm membrane lipid modification that occurs during capacitation. J Reprod Immunol 53:109-119

43. Manjunath P, Marcel YL, Uma J, Seidah NG, Chretien M, Chapdelaine A (1989) Apolipoprotein A-I binds to a family of bovine seminal plasma proteins. J Biol Chem 264:16853-16857

44. Manjunath P, Chandonnet E, Leblond E, Desnoyers SL (1994) Major proteins of bovine seminal vesicles bind to spermatozoa. Biol Reprod 50:27-37

45. Manjunath P, Lefebvre J, Jois PS, Fan J, Wright MW (2009) New nomenclature for mammalian BSP genes. Biol Reprod 80:394-397

46. McCauley TC, Zhang HM, Bellin ME, Ax RL (1999) Purification and characterization of fertility-associated antigen (FAA) in bovine seminal fluid. Mol Reprod Dev 54:145-153

47. McCauley TC, Zhang HM, Bellin ME, Ax RL (2001) Identification of a heparin-binding protein in bovine seminal fluid as tissue inhibitor of metalloproteinases-2. Mol Reprod Dev 58:336-341

48. Moura AA, Chapman DA, Koc H, Killian GJ (2006) Proteins of the cauda epididymal fluid associated with fertility of mature dairy bulls. J Androl 27:534-541 
49. Moura AA, Koc H, Chapman DA, Killian GJ (2006) Identification of proteins in the accessory sex gland fluid associated with fertility indexes of dairy bulls: a proteomic approach. J Androl 27:201-211

50. Moura AA, Chapman DA, Koc H, Killian GJ (2007) A comprehensive proteomic analysis of the accessory sex gland fluid from mature Holstein bulls. Anim Reprod Sci 98:169-188

51. Nauc V, Manjunath P (2000) Radioimmunoassays for bull seminal plasma proteins (BSP-A1/-A2, BSP-A3, and BSP-30-Kilodaltons), and their quantification in seminal plasma and sperm. Biol Reprod 63:1058-1066

52. O’Bryan MK, Baker HWG, Saunders JR, Kirszbaum L, Walker ID, Hudson P, Liu DY, Glew MD, d'Apice AJ, Murphy BF (1990) Human seminal clusterin (SP-40, 40) isolation and characterization. J Clin Investig 85:1477-1486

53. O'Bryan MK, Murphy BF, Liu DY, Clarke GN, Baker HWG (1994) The use of anticlusterin monoclonal antibodies for the combined assessment of human sperm morphology and acrosome integrity. Hum Reprod 9:1490-1496

54. Okamura N, Kiuchi S, Tamba M, Kashima T, Hiramoto S, Baba T, Dacheux F, Dacheux JL, Sugita Y, Jin YZ (1999) A porcine homolog of the major secretory protein of human epididymis, HE1, specifically binds cholesterol. Biochim Biophys Acta 1438:377-387

55. Parent S, Lefievre L, Brindle Y, Sullivan R (1999) Bull subfertility is associated with low levels of a sperm membrane antigen. Mol Reprod Dev 52:57-65

56. Petersson U, Somogyi E, Reinholt FP, Karlsson T, Sugars RV, Wendel M (2004) Nucleobindin is produced by bone cells and secreted into the osteoid, with a potential role as a modulator of matrix maturation. Bone 34:949-960

57. Reyes-Moreno C, Boilard M, Sullivan R, Sirard MA (2002) Characterization of secretory proteins from cultured cauda epididymal cells that significantly sustain bovine sperm motility in vitro. Mol Reprod Dev 63:500-509

58. Rodriguez CM, Day JR, Killian GJ (2000) Osteopontin gene expression in the Holstein bull reproductive tract. J Androl 21:414-420

59. Rodriguez-Martinez H, Saravia F, Wallgren M, Tienthai P, Johannison A, Vazquez JM, Martinez E, Roca J, Sanz L, Calvete JJ (2005) Boar spermatozoa in the oviduct. Theriogenology 63:514-535

60. Roncoletta M, Morani Eda S, Esper CR, Barnabe VH, Franceschini PH (2006) Fertility-associated proteins in Nellore bull sperm membranes. Anim Reprod Sci 91:77-87

61. Ronkko S (1992) Immunohistochemical localization of phospholipase A2 in the bovine seminal vesicle and on the surface of the ejaculated spermatozoa. Int J Biochem 24:869-876

62. Ronkko S, Lahtinen R, Vanha-Perttula T (1991) Phospholipases A2 in the reproductive system of the bull. Int $\mathrm{J}$ Biochem 23:595-603

63. Saalmann A, Munz S, Ellerbrock K, Ivell R, Kirchhoff C (2001) Novel sperm-binding proteins of epididymal origin contain four fibronectin type II-modules. Mol Reprod Dev 58:88-100

64. Saez F, Frenette G, Sullivan R (2003) Epididymosomes and prostasomes: their roles in post-testicular maturation of the sperm cells. J Androl 24:149-154

65. Sahin E, Petrunkina AM, Waberski D, Harrison RAP, TopferPetersen E (2009) Control of bull sperm cell volume during epididymal maturation. Reprod Fertil Dev 21:469-478

66. Samper JC, Hamilton DW, Pryor JL, Loseth KJ, Troedsson MHT, Crabo BG (1995) Mechanism of sephadex trapping of capacitated stallion spermatozoa. Biol Reprod (Monogr 1):729-737

67. Sato H, Taketomi Y, Isogai Y, Miki Y, Yamamoto K, Masuda S, Hosono T, Arata S, Ishikawa Y, Ishii T, Kobayashi T, Nakanishi H, Ikeda K, Taguchi R, Hara S, Kudo I, Murakami M (2010)
Group III secreted phospholipase A2 regulates epididymal sperm maturation and fertility in mice. J Clin Investig 120:1400-1414

68. Schoneck C, Braun J, Einspanier R (1996) Sperm viability is influenced in vitro by the bovine seminal protein aSFP: effects on motility, mitochondrial activity and lipid peroxidation. Theriogenology 45:633-642

69. Soubeyrand S, Khadir A, Brindle Y, Manjunath P (1997) Purification of a novel phospholipase A (2) from bovine seminal plasma. J Biol Chem 272:222-227

70. Souza CEA, Moura AA, Monaco E, Killian GJ (2008) Binding patterns of bovine seminal plasma proteins A1/A2, $30 \mathrm{kDa}$ and osteopontin on ejaculated sperm before and after incubation with isthmic and ampullary oviductal fluid. Anim Reprod Sci 105:72-89

71. Sparrow DA, Lee BR, Laplaud PM, Auboiron S, Bauchart D, Chapman MJ, Gotto AM Jr, Yang CY, Sparrow JT (1992) Plasma lipid transport in the preruminant calf, Bos spp primary structure of bovine apolipoprotein A-I. Biochim Biophys Acta 1123:145-150

72. Srivastava PN, Arbtan K, Takei GH, Huang TT, Yanagimachi R (1986) $\alpha$-L-Fucosidase from bull seminal plasma: its purification and acrosome reaction promoting property. Biochem Biophys Res Commun 137:1061-1068

73. Sullivan R, Frenette G, Lessard C, Legare C (2003) Sperm antigen acquisition in the epididymis: a role for epididymosomes. In: Hinton B, Turner TT (eds) Epididymis III. the Van Doren Company, Charlottesville, pp 130-136

74. Sutovsky P, Moreno R, Ramalho-Santos J, Dominko T, Thompson WE, Schatten G (2001) A putative, ubiquitin-dependent mechanism for the recognition and elimination of defective spermatozoa in the mammalian epididymis. J Cell Sci 114:1665-1675

75. Sutovsky P, Terada Y, Schatten G (2001) Ubiquitin-based sperm assay for the diagnosis of male factor infertility. Hum Reprod $16: 250-258$

76. Sylvester SR, Skinner MK, Griswold MD (1984) A sulfated glycoprotein synthesized by Sertoli cells and by epididymal cells is a component of the sperm membrane. Biol Reprod 31:1087-1101

77. Tedeschi G, Oungre E, Mortarino M, Negri A, Maffeo G, Ronchi S (2000) Purification and primary structure of a new bovine spermadhesin. Eur J Biochem 267:6175-6179

78. Therien I, Moreau R, Manjunath P (1998) Major proteins of bovine seminal plasma and high-density lipoprotein induce cholesterol efflux from epididymal sperm. Biol Reprod 59:768-776

79. Therien I, Moreau R, Manjunath P (1999) Bovine seminal plasma phospholipid binding proteins stimulate phospholipid efflux from epididymal sperm. Biol Reprod 61:590-598

80. Therien I, Soubeyrand S, Manjunath P (1997) Major proteins of bovine seminal plasma modulate sperm capacitation by highdensity lipoprotein. Biol Reprod 57:1080-1088

81. Topfer-Petersen E, Calvete JJ (1996) Sperm-associated protein candidates for primary zona pellucida-binding molecules: Structure-function correlations of boar spermadhesins. J Reprod Fertil Suppl 50:55-61

82. Topfer-Petersen E, Romero A, Varela PF, Ekhlasi-Hundrieser M, Dostalova Z, Sanz L, Calvete JJ (1998) Spermadhesins: a new protein family. Facts, hypotheses and perspectives. Andrologia 30:217-224

83. Urade Y, Watanabe K, Hayaishi O (1995) Prostaglandin D, E and F synthases. J Lipid Mediat Cell Signal 12:257-273

84. Weinman S, Ores-Carton D, Rainteau D, Puszkin S (1986) Immunoelectron microscopic localization of calmodulin and phospholipase A2 in spermatozoa. J Histochem Cytochem 34:1171-1179

85. Weinrauch Y, Elsbach P, Madsen LM, Foreman A, Weiss J (1996) The potent anti-Staphylococcus aureus activity of a sterile 
rabbit inflammatory fluid is due to a $14-\mathrm{kD}$ phospholipase A2. J Clin Investig 97:250-257

86. Yanagimachi R (1994) Fertilization. In: Nobil NE (ed) Physiology of reproduction. Raven press, New York, pp 189-299
87. Yuan YY, Chen WC, Shi QX, Mao LM, Yu Q, Fang X, Roldan ERS (2003) Zona pellucida induces activation of phospholipase A2 during acrosomal exocytosis in guinea pig spermatozoa. Biol Reprod 68:904-913 